\title{
Intracytoplasmic Sperm Injection in Cattle
}

\author{
Veena Unnikrishnan (1), John Kastelic and Jacob Thundathil *
}

Department of Production Animal Health, Faculty of Veterinary Medicine, University of Calgary, Calgary, AB T2N4N1, Canada; veena.unnikrishnan@ucalgary.ca (V.U.); jpkastel@ucalgary.ca (J.K.)

* Correspondence: jthundat@ucalgary.ca

check for updates

Citation: Unnikrishnan, V.; Kastelic, J.; Thundathil, J. Intracytoplasmic Sperm Injection in Cattle. Genes 2021, 12, 198. https://doi.org/10.3390/ genes12020198

Academic Editor: Pavneesh Madan

Received: 2 January 2021

Accepted: 26 January 2021

Published: 29 January 2021

Publisher's Note: MDPI stays neutral with regard to jurisdictional claims in published maps and institutional affiliations.

Copyright: (c) 2021 by the authors. Licensee MDPI, Basel, Switzerland.

This article is an open access article distributed under the terms and conditions of the Creative Commons Attribution (CC BY) license (https:// creativecommons.org/licenses/by/ $4.0 /)$.

\begin{abstract}
Intracytoplasmic sperm injection (ICSI) involves the microinjection of sperm into a matured oocyte. Although this reproductive technology is successfully used in humans and many animal species, the efficiency of this procedure is low in the bovine species mainly due to failed oocyte activation following sperm microinjection. This review discusses various reasons for the low efficiency of ICSI in cattle, potential solutions, and future directions for research in this area, emphasizing the contributions of testis-specific isoforms of $\mathrm{Na} / \mathrm{K}$-ATPase (ATP1A4) and phospholipase C zeta (PLC $\zeta)$. Improving the efficiency of bovine ICSI would benefit the cattle breeding industries by effectively utilizing semen from elite sires at their earliest possible age.
\end{abstract}

Keywords: bovine; ICSI; sperm oocyte activation factor; phospholipase C zeta

\section{Introduction}

Sustainable Development Goals of the United Nations mandate a substantial increase in global food production in the near future [1]. Canadian animal production industries are at the forefront of improving animal productivity and contribute several billion dollars annually to our national economy. They rely on a variety of reproductive technologies such as artificial insemination (AI) [2] and embryo production [3] for genetic improvement and propagation of superior germ plasm globally. Since even a modest increase in the reproductive rate in cattle enhances productivity [4], improving efficiency of reproductive technologies will have immediate and substantial benefits globally. Production of frozen semen from elite bulls (progeny testing, based on their daughters' milk production) and its use for AI have been practiced globally for dissemination of superior genetics and enhancing animal productivity. However, this industry has been recently revolutionized by genomic tools [5], facilitating early selection of superior bulls and widespread dissemination of their genetics. Reproductive technologies have substantially improved efficiency of genetic selection of bulls by reducing the generation interval from 5 years (progeny testing) to $\sim 1.5$ years [6]. Currently, industries are under pressure to market semen from bulls at their earliest possible age and AI centres are populated with younger bulls $[7,8]$. Despite the obvious benefits, this brings several challenges. Semen is now often collected from peri-pubertal bulls, yielding fewer sperm [9] of suboptimal quality [10], limiting its use for frozen semen production and AI. In response, in vitro production of embryos by in vitro fertilization (IVF) and embryo culture (IVC) or intracytoplasmic sperm injection (ICSI) are being used. Although IVF requires a minimum number of morphologically normal and functionally competent sperm for successful fertilization, ICSI with spermatogenic cells or sperm with suboptimal quality [11] was successful in several species [12-15]. Therefore, ICSI could be a viable option for the efficient use of semen of suboptimal quality (collected from young bulls) or sex-sorted. Although gametes contribute to genetic variation, selection of gametes based on genetic diversity is now possible using genomic selection [16]. Changing genetic selection from a superior animal for breeding to a superior gamete within an individual is not far from reality, as software that can identify gametic variance is already available [16]. Advancements in gametic selection would be an impetus 
for assisted reproductive techniques like ICSI for the efficient use of selected gametes for embryo production. Although this technique was developed for several species, i.e., rodents [17,18]; humans [19]; horses [20]; and swine [21], its success is not optimal in cattle, for various reasons. This review is focused on ICSI in cattle, with an emphasis on its applications, efficiency, reasons for ICSI failure, recent development, and future directions of research. The emphasis will be on sperm treatment and its contributions to the success of ICSI in cattle. ICSI is an in vitro technique in which a single sperm is microinjected into the cytoplasm of a matured oocyte. This technique is used to overcome infertility in humans and domestic animals. However, the technique was first performed using hamster sperm and oocyte, which produced a male pronucleus [14]. Thereafter, ICSI replaced conventional failed in vitro fertilisation in humans, where the sperm from oligospermic and asthenozoospermic patients were unable to fertilize oocytes. In addition, ICSI has been used in livestock and wild animals for improving livestock productivity, biodiversity conservation, transgenic animal production, e.g., pig [22] and for fertilization problems in IVF systems, e.g., horses $[23,24]$, plus fundamental research in reproductive biology.

The first ICSI was performed with an in vitro-matured bovine oocyte by injection of sperm, resulting in embryo development up to a blastocyst and its transfer into a surrogate, with birth of viable offspring [25]. Thereafter, there were reports of successful birth of live calves $[26,27]$. Furthermore, ICSI-derived fully expanded blastocysts have survivability and quality similar to IVF-derived blastocysts after slow freezing [28] or vitrification [29]. As cryopreservation has become an integral part of assisted reproductive technology [28], development of better freezing protocols for cryopreservation of in vitro-produced embryos would also help to preserve ICSI-derived embryos, including genetic conservation of wild bovine species.

\section{Applications of Bovine ICSI}

Earlier, ICSI was used as a last resort when IVF failed. Viable embryos were produced from various types of spermatogonic cells, e.g., spermatids [30] and sperm obtained from in vitro culture of secondary spermatocytes [11]. Microinjection of bovine heatdried [31] or freeze-dried [32] sperm yielded blastocysts. ICSI would be beneficial in preservation and conservation of endangered bovine species using lyophilised [32] or heat-dried sperm [31]. Frozen-thawed bovine oocytes are suitable for ICSI, as this improves pronuclear formation [33] and cleavage rate [34] compared to IVF with frozen-thawed bovine oocytes. Hence, in vitro production of bovine embryos with gametes of variable quality (blastocyst rate formation in good vs. poor quality oocytes was $23.3 \%$ and $11.1 \%$ respectively) can be effectively achieved with ICSI [35].

Sex-sorted sperm have been used to produce female dairy and male beef calves, using in vitro production of embryos [36]; this has substantially advanced cattle productivity, including propagation of genetics from superior cattle that are culled due to injuries [37]. Availability of frozen sex-sorted bovine sperm increases the use of IVF in cattle breeding programs [38]. However, embryos resulting from in vitro fertilization using sex-sorted sperm had poor developmental competence, and the resulting embryos had poor calving rates [36]. Jo et al. (2014) reported that ICSI of sex-sorted sperm (24.7\%) yielded more embryos than IVF $(2.7 \%)$ of sex-sorted sperm [39], encouraging its use to produce sexspecific embryos [40].

ICSI has been effectively used for production of transgenic embryos [41-44]. Spermmediated gene transfer uses sperm to transport exogenous DNA into the oocyte during fertilization, resulting in transgenic embryos [42]. In farm animals such as sheep, goats and cattle, transgenesis has been used to generate animals that express recombinant protein in milk, or to produce porcine organs for human xenotransplantation [43]. Intracytoplasmic sperm injection mediated gene transfer (ICSI-MGT) has benefits over pronuclear microinjection as it eliminates low transgenic efficiencies and imprinting defaults inherent in somatic cell nuclear transfer (SCNT) [41]. Bovine blastocyst production with ICSI-MGT was comparable to or better than SCNT or pronuclear microinjection [41]. High blastocyst 
production was achieved in farm animal ICSI-MGT by chemical activation of oocytes using ionomycin and 6-dimethylaminopurine (DMAP) [41,43]. In addition, physical or chemical damage to the sperm membrane before microinjection improved ICSI-MGT [42].

Bovine ICSI has contributed to the assessment of oocyte activation [45] and centrosome function [45-49] of human sperm. Bovine ICSI has also been used as a heterologous assay system $[47,50,51]$ for evaluating fertilising ability of human sperm [45] and human centrosome function [46,52]. These assays have led to identification of the role of male pronuclei in synchronising development of female pronuclei [50].

\section{Potential Reasons for Failure of ICSI in Cattle}

The success rate of ICSI in cattle $(14 \%)$ is low compared to other domestic species (horse: $21 \%$, goat: $28 \%$ and pig: $18 \%$ ) [53]. However, since ICSI has tremendous potential for augmenting genetic selection and animal productivity, research is ongoing to improve its efficiency. Major reasons for the failure of ICSI in cattle were regarded as the inability of sperm to undergo nuclear decondensation and pronuclei formation [54], improper functions of microtubule organising centre [55], and failure to elicit calcium oscillations [56] required for oocyte activation. In Vitro-matured bovine oocytes are incapable of processing sperm with an intact acrosome or sperm that has not undergone capacitation [54]. It has been reported that the acrosomal enzymes deform and lyse oocytes [57]. Furthermore, when sperm from various species (hamster, cattle, swine, human and mouse) were microinjected to mouse oocytes, the order in which they cytolyse the oocyte was correlated with acrosome volume. Injecting trypsin and hyaluronidase (which mimicked action of acrosome-intact sperm) into a normal, fertilized mouse oocyte disturbed pre- and postimplantation development [57]. However, removal of sperm membranes may improve male pronuclei formation [58] and make the sperm-derived oocyte activating factor (PLC zeta) more readily available to the oocyte cytoplasm. Compromised release or activation of sperm factor may cause failure of calcium oscillation [56].

During fertilization, calcium oscillation precedes oocyte activation. Fusion of sperm and oocyte releases sperm oocyte activation factor (PLC zeta) which is involved in the hydrolysis of phosphatidyl inositol biphosphate (PIP2), generating inositol triphosphate (IP3) and diacetyl glycerol (DAG). IP3 binds to receptors in the intracellular calcium reserves (e.g., endoplasmic reticulum), releasing calcium [59-61]. Oocytes have a second messenger-controlled activation model, with calcium and IP3 as second messengers. Increased intracellular cytosolic calcium concentrations induce calcium oscillations by activating calcium-induced calcium release (CICR), whereby calcium induces its own release from internal reservoirs [62]. Furthermore, calcium oscillations are maintained by calcium transients, which, depending on the time taken by the calcium stores to replenish calcium to facilitate the next spontaneous discharge [62]. The IP3-mediated increase in intracellular calcium is a feedback to inhibit further calcium release by inactivating calcium channel receptors, thereby forcing calcium back to internal reservoirs. This decrease in calcium removes the feedback inhibition on IP3-sensitive calcium channels and calcium oscillations are maintained by the periodic release of calcium from an IP3-sensitive calcium pool [62]. Thus, calcium oscillation promotes oocyte activation, manifested by the resumption of meiosis and formation of male and female pronuclei.

Changes during bovine capacitation and acrosome reaction during in vivo fertilization might favour release or activation of sperm factor. The sperm oocyte activation factor is apparently located at the perinuclear theca [63]. Persistence of the subacrosomal region of perinuclear theca (SAR-PT) on the apex of the male pronucleus disrupts the S-phase, not only in the male, but also in the female pronuclei [64,65]. In a primate study, complete solubilisation of post-acrosomal sheath perinuclear theca (PAS-PT) seemed to occur in parallel with oocyte activation [66]. Therefore, it is likely that greater rigidity of the perinuclear theca of bovine sperm [67] contributes to its difficulty in solubilisation of the perinuclear theca contents [66], and sperm nuclear stability [68] to its difficulty in sperm decondensation. Bull sperm microinjected into oocyte removed its plasma membrane 
after $20 \mathrm{~h}$, but there was no sign of perinuclear theca removal, likely affecting the ability of oocyte factors to access sperm DNA and also preventing sperm decondensation [67]. The latter involves replacement of sperm protamines by oocyte-derived histones and is a pre-requisite for male pronuclear formation [69].

Condensation of the sperm nucleus is the result of protamine binding to the DNA [70]. The protamine is rich in cysteine and arginine. It binds to DNA mainly by electrostatic interaction of its arginines. The aggregation is further stabilized by inter- and intra-disulphide bonds [71]. In mammals, two distinct protamines are present, protamine 1 and protamine 2 [72]. Bull sperm has only protamine 1 and the nuclear chromatin is very stable with maximum number of disulphide cross links [70]. Bovine protamine 1 has central argininerich DNA binding domain and cysteine-rich domain at both ends [73]. Each cysteine sulfhydryl group is oxidised to intra- and intermolecular disulphide bridges [74]. Affinity to DNA is greater for protamine 1 versus protamine 2 [72]. The latter (present in human and mouse), has lower cysteine content than the former, so protamine 2 is expected to have lower disulphide bridges [75]. Therefore, sperm with a higher proportion of protamine 2 decondense quickly [54], accounting for lower stability of human and mouse sperm nuclei (contain protamine 2) compared to bull sperm.

Furthermore, to accurately nucleate and organise the sperm aster, the ooplasmic pericentriolar materials should be properly blended with sperm centrosomes [76]. Microtubule organising centres (MTOC) of sperm-microinjected oocytes (aster formation rate and fluorescent intensity of microtubule network) were not as functional as those of IVF oocytes [55]. Similarly, inadequate oocyte activation and male pronuclei formation may be due to compromised in vitro oocyte maturation, decreasing inositol-1,4,5-triphosphate (IP3) and glutathione reserves in cumulus cells [77]. A recent report using transcriptional regionalisation of developmental genes within M-II bovine oocytes and a preferential sperm entry point during IVF [78] implied oocytes may be polar. Consequently, the sperm entry point during ICSI may be important in embryo development [78]. Developing culture conditions [79] to improve ooplasmic environment [54] and mimicking molecular changes in sperm associated with physiological capacitation and acrosome reaction [54] through appropriate sperm pre-treatments, may increase efficiency of ICSI in cattle.

\section{Pre-Treatment of Sperm for Improving the Success of Bovine ICSI}

Effects of various pre-treatments on sperm were provided in Table 1. Mechanical pretreatment of sperm by immobilisation of sperm by tail scoring improved male pronucleus formation $[80,81]$ as localized disruption of sperm plasma membrane is expected to promote its disintegration within the oocyte [82]. The sperm plasma membrane is unable to heal, compared to other cells, due to minimal cytoplasm [83]. Through the disrupted membrane, extracellular sodium and calcium ions move inside the sperm, activating endogenous nucleases that cleave DNA. Consequently, it is important to minimize the interval between sperm immobilisation (disruption of sperm plasma membrane) and sperm injection into an oocyte [83]. For species with a stable plasma membrane (e.g., cattle), it is optimal to disrupt this membrane prior to ICSI [84].

Chemical pre-treatment of sperm improved ICSI outcome in cattle [80] by increasing nuclear decondensation and pronuclei formation. As bovine ICSI bypasses critical fertilisation events, e.g., capacitation, acrosome reaction and penetration of zona pellucida [77], there is a need to artificially subject sperm to these changes. Dithiothreitol (DTT) pre-treatment of sperm before bovine ICSI improved cleavage rate [85] and blastocyst development in OPU-ICSI when compared to OPU-IVF [86]. Treatment of oocytes and sperm with DTT without any oocyte activation agent resulted in the birth of a healthy calf [87]. Conversely, there are reports that sperm pre-treatment with DTT [88,89] along with oocyte activation with DMAP improved the efficiency of bovine ICSI. DTT reduces the disulphide bond necessary for sperm nuclear decondensation [90] and destabilizes the nuclear packaging of sperm head. DTT also nucleates the microtubules by organising Y-tubulin in the sperm centrosome. The Y-tubulin would access the microtubule com- 
ponents present in the ooplasm by the conformational change induced by reducing the disulphide bonds in sperm centrosome [76]. DTT is a thiol compound with two thiol groups. The reactivity of dithiol depends on its pKa value. When the pKa of a DTT is approximately equal to the $\mathrm{pH}$ of the media in which it is dissolved, the thiol-disufide interchange is maximal. The pKa of DTT is 9.0, greater than fertilization medium (7.8), so its active form (reduced DTT) is easily converted to inactive form (oxidised DTT) [74]. Recently a dithiol group, dithiolbutylamine (DTBA) increased the efficacy of blastocyst production in bovine ICSI [74]. DTBA is more efficient than DTT in preventing re-oxidation of sperm and can promote pronuclei formation, as it can be retained longer in sperm, due to its pKa of 8.2. Moreover, longer incubation of sperm with DTT increases DNA fragmentation and significantly reduces sperm viability compared to DTBA [74]. In addition, DTT predisposes sperm to chromosomal abnormalities [91]. Pre-treatment of sperm with glutathione (GSH) [92], plus oocyte activation by ionomycin in combination with ethanol, improved the efficiency of bovine ICSI. Hence, the detrimental chemical thiol compound pre-treatment (e.g., DTT) can be replaced by glutathione (GSH) [91,92], a major non-protein thiol compound naturally present in mammalian cells. GSH is involved in many cellular functions including disulphide bond reduction, protection against oxidative stress, etc. Although disulphide bond reduction is faster with DTT than GSH, the latter causes higher disulphide bond reduction rate (Figure 1). In ICSI, GSH can function with fewer side effects than DTT, reducing disulphide bonds and promoting sperm chromatin decondensation in vitro [91].

Ejaculated sperm must reside in the female reproductive tract for a species-dependent interval for its final maturation through a series of biochemical changes, (capacitation) enabling fertilizing ability. Pre-treatment of bovine sperm before ICSI with a capacitating agent, e.g., M $\beta C D$ (methyl- $\beta$-cyclodextrin) [93], heparin [81,94] and heparin with glutathione (GSH) significantly improves fertilization and blastocyst formation rates [95,96]. Heparin + GSH improved the outcome of ICSI from sex-sorted sperm [96]. Heparin is a polyanionic glycosaminoglycan (GAG); these are compounds present in both male and female reproductive tract secretions and with important roles in fertilization [97]. Also, heparin and heparin-like GAGs in the oviduct contribute to capacitation of bovine sperm $[98,99]$. There are receptors for heparin present on sperm plasma membranes. It has been proposed that destabilisation of sperm plasma membrane occurs when heparin bind to its receptors, enabling incorporation of other molecules (e.g., GSH) into the sperm nucleus $[75,100]$. Heparin can decondense human sperm [101]. It has a strong affinity for protamine, forming a highly insoluble complex [75]. Sperm decondensation is dependent on the sulphation characteristics of heparin rather than a polyanionic molecule competing with DNA for positively charged protamines [101]. The desulphation effects of heparin affect the net charge, resulting in electrostatic interactions between charged groups and inducing conformational changes [101]. Furthermore heparin or heparin sulphate (a heparin analogue) were implicated in removal of sperm protamines [102] and heparin sulphate has been identified in oocytes, implying it may be involved in sperm decondensation, acting as a protamine acceptor [103]. In bull sperm, nuclear decondensation is induced by heparin [70] and heparin-GSH [97]. GSH treatment enhanced mitochondrial function in the sperm middle piece and significantly reduced the number of disulphide bonds in the sperm head [91]. The sperm plasma membrane may act as a barrier against sperm decondensation, but capacitated sperm with altered sperm plasma membranes were able to undergo nuclear decondensation when heparin and GSH used as decondensing agents [102]. Furthermore, addition of GSH [79] or heparin [94] to the ICSI culture medium improved embryo development, emphasizing the importance of pre-ICSI capacitation. 
A) Sperm nuclear decondensation by Glutathione

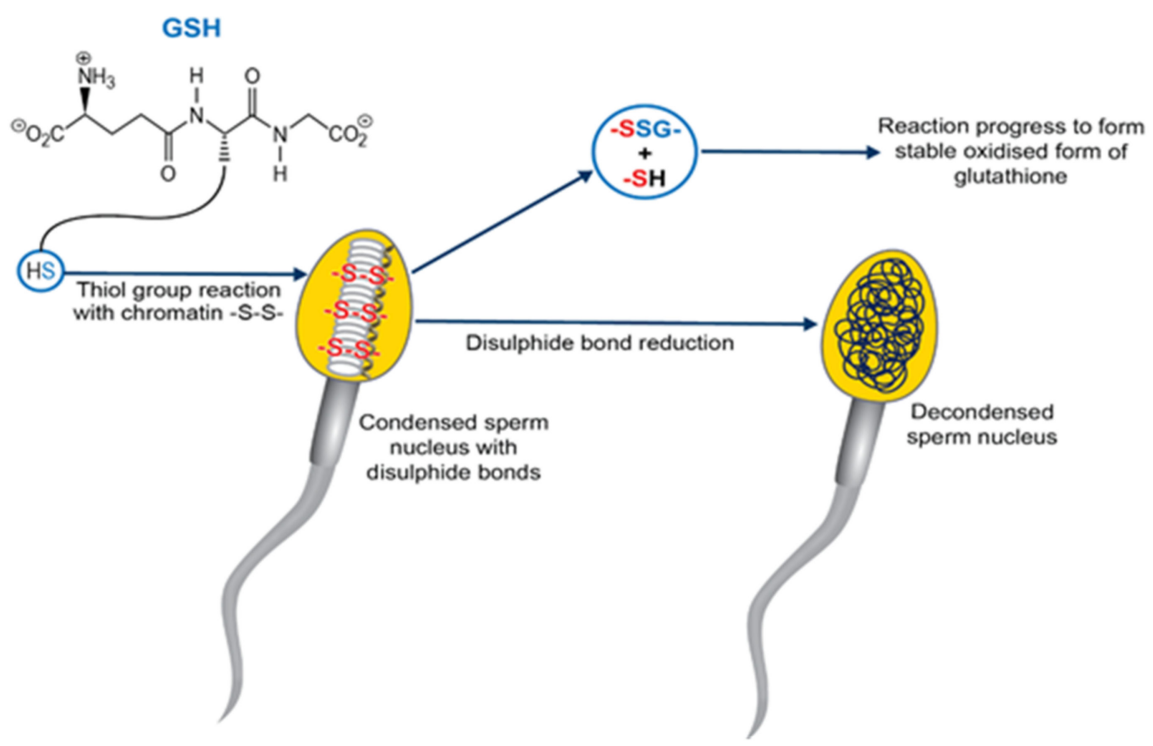

B)

Sperm nuclear decondensation by DTT

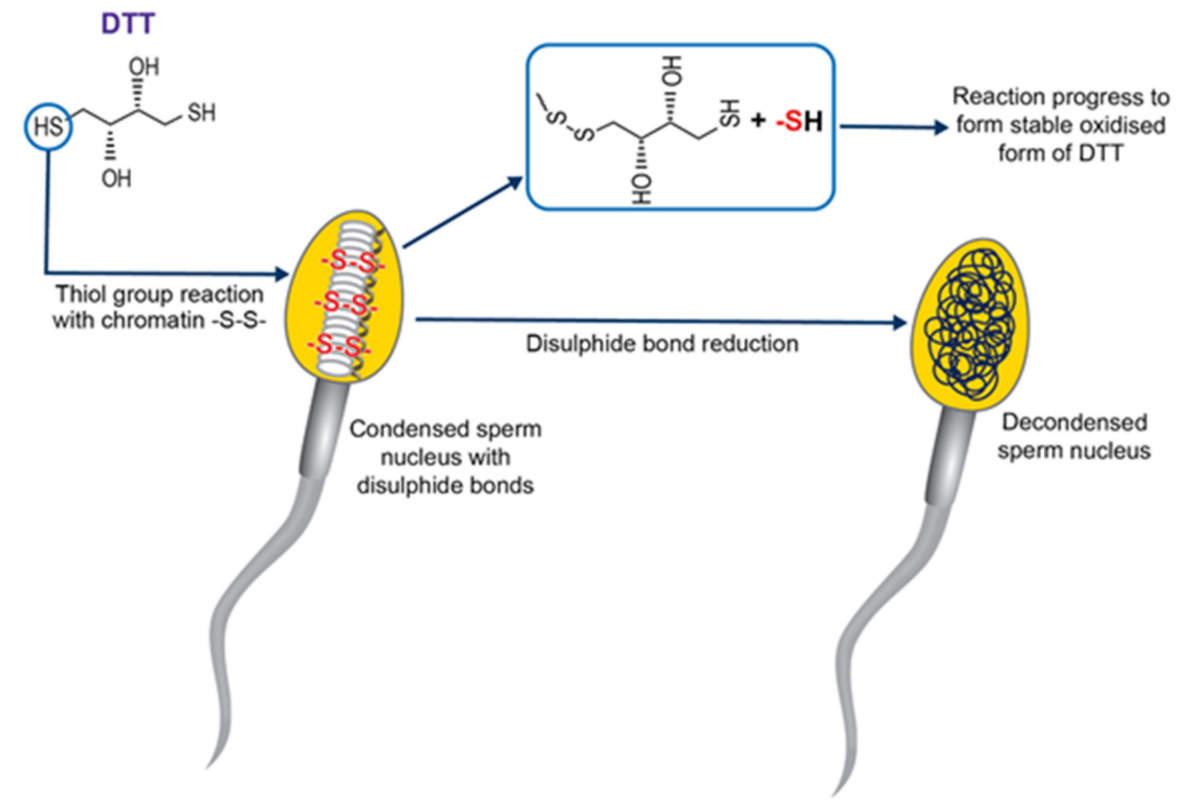

Figure 1. Sperm nuclear decondensation by disulphide bond reduction by thiol reagents. (A) Glutathione (GSH) reduces the disulphide bond in a condensed sperm nucleus, forming a mixed disulphide compound (-GSS-), along with a sulfhydryl compound (-SH). The reaction further progresses in the presence of thiol transferases enzymes, forming more stable oxidised GSH, using another molecule of GSH. Reduction of the disulphide bond results in decondensation of the sperm nucleus. (B) Dithiothreitol (DTT), a dithiol compound, reduces disulphide bonds in the condensed sperm nucleus, resulting in its decondensation. The reaction results in the formation of a sulfhydryl compound (-SH) and mixed disulphide compound (involving sulphur from DTT and sulphur from sperm nucleus), resulting in immediate reorganisation of its disulphide bond to form more stable oxidised DTT. This thiol-disulphide exchange is maximum when media pH equals pKa of DTT (9.0).

Pre-treatment of bovine sperm with detergents e.g., lysolecithin (LL) or Triton X100 (TX) [104] along with glutathione before ICSI, induces plasma membrane disruption and promotes nuclear decondensation [104]. The former improved the rate of embryonic 
development, without affecting embryo quality [104]. These detergents act as membrane destabilising agents, promoting release of acrosomal content from the sperm head [104]. Recently, bovine ICSI outcomes were improved by using cysteamine (Cys) during in vitro maturation (IVM) of oocytes and pre-incubating sperm with mature COCs (cumulus oocyte complexes) before ICSI [105]

Table 1. Effect of various pre-treatments on bovine sperm.

\begin{tabular}{|c|c|c|}
\hline Pre-Treatment & Effect on Sperm & Reference \\
\hline $\begin{array}{l}\text { Mechanical pre-treatment } \\
\text { Tail scoring } \\
\text { Piezo pulses }\end{array}$ & Removal of sperm membrane & $\begin{array}{l}{[80]} \\
{[81]}\end{array}$ \\
\hline \multicolumn{3}{|l|}{ Chemical pre-treatment } \\
\hline DTT & $\begin{array}{l}\text { Reduction of disulphide bond (sperm head decondensation) and } \\
\text { involved in microtuble organisation }\end{array}$ & [85-89] \\
\hline $\mathrm{NaOH}+\mathrm{DTT}$ & Sperm decondensation and DNA fragmentation & [106] \\
\hline DTBA & Disulphide bond reduction & [74] \\
\hline $\mathrm{LL}+\mathrm{TX}-100$ & Membrane destabilization & [104] \\
\hline $\mathrm{LL}+\mathrm{TX}+$ glutathione & Membrane destabilization and disulphide bond reduction & [107] \\
\hline \multicolumn{3}{|l|}{ Pre-treatment with capacitating agents } \\
\hline $\mathrm{M} \beta \mathrm{CD}$ & Capacitation-associated changes & [93] \\
\hline Heparin & Capacitation-associated changes and Sperm decondensation & {$[80,94]$} \\
\hline Heparin + Glutathione & $\begin{array}{l}\text { Capacitation-associated changes and disulphide bond reduction Sperm } \\
\text { decondensation. Enhanced mitochondrial function }\end{array}$ & {$[95,96]$} \\
\hline Heparin + Caffeine & $\begin{array}{l}\text { Capacitation associated changes and acrosome reaction, Sperm } \\
\text { decondensation }\end{array}$ & {$[80,108]$} \\
\hline Glutathione & $\begin{array}{l}\text { Disulphide bond reduction (sperm head decondensation). Enhanced } \\
\text { Mitochondrial function }\end{array}$ & {$[91,92]$} \\
\hline Cumulus oocyte complexes (COCs) & Acrosome reaction of sperm & [105] \\
\hline
\end{tabular}

\section{Artificial Activation of Oocyte for Improving the Success of Bovine ICSI}

Chemical or mechanical activation of the oocyte after ICSI has been commonly done in cattle. In that regard, use of electric stimulation [109], mechanical pre-treatment [80], or chemicals such as ethanol [110], ionomycin, anisomycin (ANY), cycloheximide (CHX), DMAP, dehydroleucodine (DhL) [111] independently or in various combinations, have been reported. Oocyte activation with ethanol alone or in combination with cycloheximide $[112,113]$ or ionomycin $[92,114]$ following ICSI resulted in development of blastocysts. Piezo-driven ICSI more efficient than conventional ICSI [81], and resulted in production of bovine offspring $[115,116]$ when combined with ethanol oocyte activation. Viable calves were efficiently produced by post-ICSI oocyte activation with ethanol, compared to activation with ionomycin alone or a combination of ionomycin + DMAP [117]. Ethanol activates oocytes by increasing concentrations of intracellular free calcium [118]. The stimulus of sperm is sufficient to lower the maturation promoting factor (MPF) activity after ICSI and ethanol maintains the low MPF activity until the start of the next cell cycle [110]. MPF is a non-species specific ubiquitous cytoplasmic heterodimer protein whose activity is sensitive to calcium; its elevated activity is required for the metaphase II arrest of meiosis in oocytes [119]. MPF consist of cdc2 kinase which is associated with cyclin B [120,121]; activation of this kinase is dependent on its phosphorylation state [122]. Activity of a c-mos protooncogene product called cytostatic factor [123,124] stabilises MPF and promotes the arrest of oocyte at metaphase II [119]. The intracellular calcium surge induced by ethanol inactivates the cytostatic factor. Alternatively, cycloheximide inactivates MPF by preventing the synthesis of nascent proteins and degradation of cyclin B. Therefore, a combined synergistic treatment of ethanol and cycloheximide forces the oocyte out of metaphase stage of cell cycle and results in its activation [113]. 
Ionomycin in combination with DMAP $[125,126]$, cycloheximide $[28,83]$ or roscovitine [127] have been used in bovine oocyte activation protocols [128]. Intracytoplasmic injection of round sperm resulted in efficient production of developmentally competent embryos with repeated ionomycin activation, followed by cycloheximide treatment [28]. The interval between the addition of ionomycin and DMAP has a crucial role in bovine ICSI [125]. However, delaying the addition of DMAP resulted in production of activated oocytes with reduced chromosomal abnormalities [126]. DMAP inhibits protein phosphorylation after oocyte activation. Also, DMAP accelerates post-fertilisation events by inhibiting DMAP-sensitive kinases, implicated in the formation of the interphase network of microtubules, remodeling of sperm chromatin and pronucleus formation [129]. Among the MPF inhibitors used for oocyte activation, roscovitine is one of the most effective, with fewer detrimental effects [130]. Anisomycin for oocyte activation has resulted in superior developmental rates of resulting embryos, compared to cycloheximide and DMAP [131,132]. Anisomycin is a protein synthesis inhibitor that acts specifically in the translational stage [133]. Oocyte activation can also be induced without any artificial oocyte activation agent. For example, injection of PLCZ1 (sperm oocyte activation factor) cRNA resulted in calcium oscillatory pattern and embryos with low levels of aneuploidy [134]. Injection of bovine sperm cytosolic extracts (contain sperm oocyte activation factor) activated bovine oocytes and resulted in second polar body extrusion [135]. These studies suggested the possibility of replacement of chemical pre-treatment of sperm and chemical oocyte activation agents with capacitating agents and sperm oocyte activation factor to produce embryos in vitro by ICSI.

\section{Sperm Oocyte Activation Factors (SOAFs)}

According to the sperm factor hypothesis, a soluble sperm factor is released into the oocyte and triggers oocyte activation [136-138]. Advances in calcium imaging and clinical experiments involving ICSI (intracytoplasmic sperm injection) have provided substantial evidence for this hypothesis, leading to dismissal of the receptor-based mechanism of oocyte activation $[139,140]$. The search for possible sperm oocyte activation factors (SOAF), resulted in several candidate proteins, e.g., oscillin, glucosamine-6-phosphate isomerase (GPI) and citrate synthase [136,141]. Despite experiments supporting calcium oscillation activity in mammalian oocytes, there is no convincing evidence for describing its role in mammalian fertilisation [142].

Phospholipase C (PLC) isoforms catalyse hydrolysis of PIP2 (phosphatidyl inositol biphosphate) to inositol triphosphate (IP3) and diacyl glycerol (DAG). Thereafter, IP3 releases calcium via a receptor localised on the surface of the endoplasmic reticulum and DAG and calcium together activate the protein kinase C (PKC) pathway, resulting in cellular responses $[137,143,144]$. Moreover, previous studies characterized and identified a sperm-specific PLC isoform, PLC zeta (PLC $\zeta$ ) as a candidate for the oocyte activation factor $[60,140,142,145]$. Furthermore, a post acrosomal WW-domain binding protein (PAWP) was a candidate for SOAF [146]. Microinjection of the PAWP cRNA or recombinant PAWP into porcine, bovine, Xenopus, mouse or human oocytes resulted in calcium oscillations, similar to those with ICSI and oocyte activation. Sperm inhibited with a competitive inhibitor for PAWP-derived PPGY peptide prevented the calcium oscillation $[146,147]$. PAWP is localised to the post acrosomal sheath-perinuclear theca of sperm head; it has an $\mathrm{N}$-terminal with a sequence homology to WW-domain binding protein 2 and proline-rich C-terminal with a PPXY binding site and unknown repeating motif [146-148]. A hypothetical model on how this PAWP triggers calcium oscillation has been suggested $[146,147]$. It is thought to bind to oocyte-borne YAP protein and interact with the SH3 domain of PLC $\gamma$, activating a phosphatidyl inositol pathway $[146,147]$. Ever since the introduction of PAWP, it emerged to question the PLC $\zeta$ as SOAF. A study comparing the calcium oscillation in mouse oocyte by the microinjection of recombinant PAWP and PLC $\zeta$ reported that recombinant PLC $\zeta$ resulted in calcium oscillations similar to those in mammalian fertilization, whereas recombinant PAWP did not. Consequently, PAWP is not a convincing 
SOAF candidate [149]. Moreover, independent laboratories have validated the role of PLC $\zeta$ as a SOAF in a replicable and reliable manner $[60,139,150-153]$.

\section{PLC $\zeta$ as a Sperm-Specific Oocyte Activating Factor}

In most mammalian species, an ovulated oocyte is arrested at Metaphase-II [154]. Oocyte activation normally occurs immediately following sperm penetration of the oocyte [155], triggered by a series of calcium waves [156], leading to resumption of meiosis, formation of male and female pronuclei, and fusion of these pronuclei leading to zygote formation. It has been established that a sperm-specific PLC $\zeta$ (located in the sperm head) is the sperm-derived oocyte activating factor [60,139,150-153]. The PLC $\zeta$ has been identified in several mammalian species (rats: [157]; pigs: [158]; cattle: [132]; monkeys and humans: [159]). Immunodepletion of PLC $\zeta$ from sperm protein extracts completely abolished calcium oscillation-inducing activity of sperm extracts [60]. There is mounting clinical evidence implicating involvement of abnormal, aberrant and mutant forms of PLC $\zeta$ resulted in failure of egg activation $[150,151,153]$. Microinjection of sperm heads lacking PLC $\zeta$ failed to activate oocytes, due to either no calcium oscillation or diminished calcium profiles in humans $[150,151]$. It has been proposed that PLC $\zeta$ elicits calcium oscillations in oocytes through a phosphoinositide signalling pathway, by hydrolysing membrane-bound phosphatidylinositol 4,5-bisphosphate (PIP2), resulting in the release of inositol triphosphate (IP3), which in turn binds to the IP3 receptors in intracellular calcium reserves, leading to intracellular calcium oscillations $[59,60]$. However, mechanisms of PLC activation eliciting calcium waves immediately following sperm penetration remain unknown.

\section{A Hypothetical Model for PLC $\zeta$ Activation during Sperm Capacitation}

Bull sperm can be capacitated in vitro by incubating with capacitating agents [heparin; ouabain, a cardiac glycoside; or a combination of cAMP and IBMX (a phosphodiesterase inhibitor) at $39{ }^{\circ} \mathrm{C}$ under $5 \% \mathrm{CO}_{2}$ and high humidity]. The activity of PIP2-PLC is higher in capacitated versus uncapacitated sperm [160], suggesting a capacitation-associated increase in PLC $\zeta$ activity, with key roles in regulation of sperm capacitation and fertilization. However, the molecular basis of this PLC $\zeta$ activation and the role of specific capacitating agents in this process remains unknown.

The ubiquitous and testis-specific isoforms of Na/K-ATPase (ATP1A1 and ATP1A4, respectively), are present in bull sperm. Interaction of ouabain, a cardiac glycoside, with $\mathrm{Na} / \mathrm{K}-\mathrm{ATPa} e$ regulates sperm capacitation [161]. ATP1A4 interacts with several proteins [162], including phospholipase C zeta (PLC) [163]. Significance of the interaction between ATP1A4 and PLC $\zeta$ during bull sperm capacitation is unknown. Capacitation includes tyrosine phosphorylation (Y-p) of sperm proteins [69,164], actin remodelling [165] and hyperactivated motility [166]. Incubation of bovine sperm with ouabain induced tyrosine phosphorylation and an acrosome reaction [167] via PKA, RTK and Src kinases [168] and ERK [169]. That PLC $\zeta$ exerts its effect immediately following sperm penetration of the oocyte implies it is already active at the time of sperm penetration. In LLC-PK1 cells, ATP1A1 tethers PLC- $\gamma 1$ and IP3 receptors to form a Ca2 ${ }^{+}$-regulatory complex and ouabaininduced phosphorylation of PLC- $\gamma 1$ at Tyr (783) activated PLC- $\gamma 1$ in a Src-dependent manner [170]. Ouabain-induced capacitation co-localized PLC $\zeta$ and ATP1A4 to the postacrosomal region of sperm head [163] and confirmed their interaction, perhaps activating PLC $\zeta$, generating IP3 and diacyl glycerol (DAG) in sperm. IP3 binds to IP3R, increasing intracellular $\mathrm{Ca}_{2}^{+}$, whereas DAG-mediated activation of PKC converts globular actin (Gactin) to filamentous-actin (F-actin), essential for capacitation Figure 2; [171]. Therefore, the role of ATP1A4-induced activation of PLC $\zeta$ in filamentous-actin formation during capacitation and triggering calcium oscillations (through PLC $\zeta$-mediated cleavage of PIP2 and generation of IP3) during sperm-oocyte fusion warrant further research (Figure 3). 


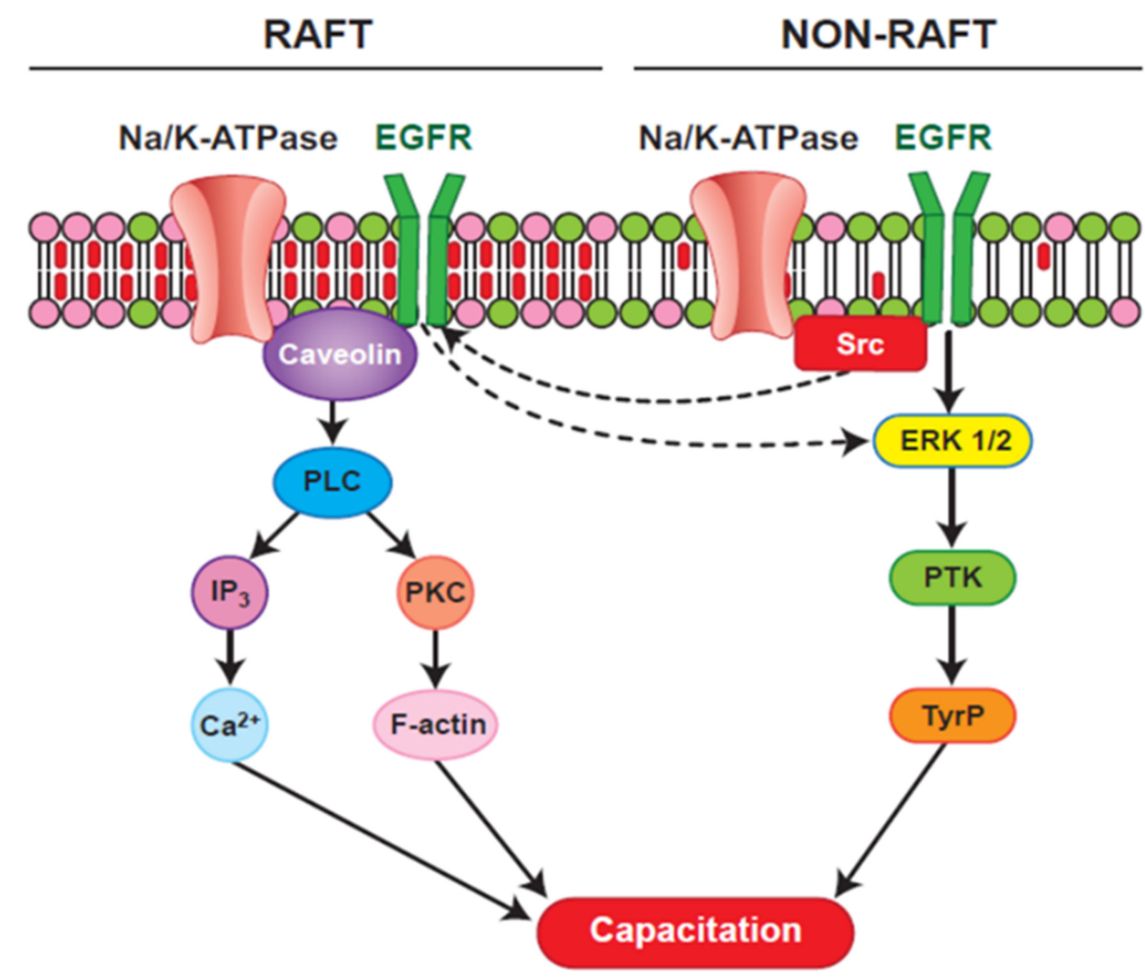

Figure 2. A hypothetical model for ATP1A4 (Na/K-ATPase $\alpha 4)$-mediated raft- and non-raft signaling pathways during bovine sperm capacitation [172]; reproduced with permission from John Wiley and Sons and Copyright Clearance Center]. Both raft and non-raft pools of ATP1A4 could activate downstream pathways during sperm capacitation. In the raft, ouabain signaling involves ATP1A4-caveolin-1-EGFR (epithelial growth factor receptor) complex which could bind and activate PLC (phospholipase C), thereby increasing hydrolysis of PIP2 (phosphatidylinositol biphosphate), generating IP3 (inositol triphosphate) and DAG (diacyl glycerol), which in turn activates PKC (phosphokinase C). IP3 binds to IP3R (inositol triphosphate receptors), increasing intracellular calcium, whereas PKC mediates polymerisation of G-actin to F-actin through other mediator proteins. Within non-raft, ATP1A4 signaling activates ERK1/2 (extracellular signal regulated protein kinase 1/2, a mitogen activated protein kinase) through activation of Src (Src kinase, a non- receptor tyrosine kinase), leading to PTK (protein tyrosine kinase) mediated tyrosine phosphorylation of proteins. Increase in Factin, intracellular calcium and protein tyrosine phosphorylation contribute to capacitation-associated changes in sperm.

In summary ICSI is a very reliable and efficient reproductive technique. Improved fertilisation from sex-sorted sperm and gametes with variable quality is the advantage of ICSI over other reproductive techniques. Additionally, its use in gene transfer makes it more valuable. ICSI is not successful in cattle due to difficulties in sperm nuclear decondensation, functioning of microtubule organising centre, and oocyte activation. Furthermore, anatomical peculiarities of bovine sperm also contribute. However, various sperm pretreatment and oocyte activating agents have improved bovine ICSI. Sperm for ICSI is not undergoing capacitation, an essential event in natural fertilisation. Sperm pre-treatment using capacitating agents have improved efficiency of bovine ICSI. That the major reason for the failure of bovine ICSI is mainly due to sperm, focusing research in this direction is warranted. 


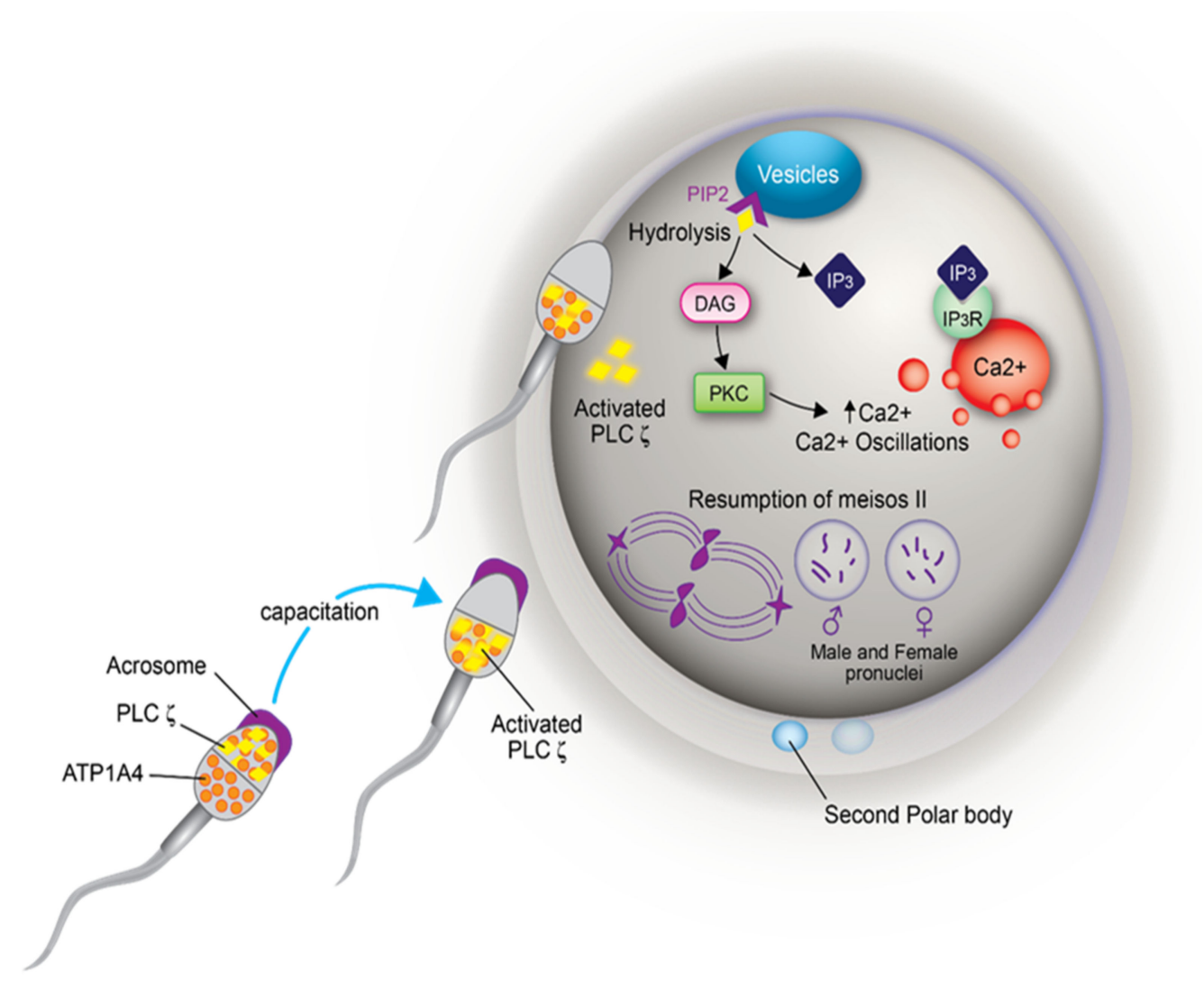

Figure 3. A hypothetical model depicting the involvement of ATP1A4 (Na/K-ATPase $\alpha 4$ ) mediated activation of PLC $\zeta$ (phospholipase C zeta) and the involvement of activated PLC $\zeta$ in oocyte activation. In fresh sperm, ATP1A4 is localized to the entire sperm head and PLC $\zeta$ to the acrosomal region. In capacitated sperm, both proteins are co-localized to the post-acrosomal region. The interaction of these two proteins during capacitation activates PLC $\zeta$. Following sperm penetration, the equatorial segment of the sperm head fuses with the oolemma, resulting in the release of activated PLC $\zeta$ into the oocyte cytoplasm. This activated PLC $\zeta$ binds to PIP2 (phosphatidylinositol biphosphate) substrate, present in small vesicles inside the oocyte, resulting in its hydrolysis and formation of IP3 (inositol triphosphate) and DAG (diacyl glycerol). IP3 binds to its receptor in intracellular calcium reserves and releases calcium, thereby increasing intracellular calcium ion concentrations. In addition, DAG activates PKC (protein kinase C), which also increases calcium concentration resulting in calcium oscillation. This calcium oscillation results in resumption of meiosis of the metaphase II-arrested oocyte, expulsion of the second polar body and formation of a female pronucleus. Concurrently, sperm nuclear decondensation occurs, resulting in formation of the male pronucleus. Fusion of male and female pronuclei results in zygote formation.

Author Contributions: V.U.: Writing—original draft preparation; J.T. and J.K.: Writing-review and editing; All authors have read and agreed to the published version of the manuscript.

Funding: Received funding from the Natural Sciences and Engineering Research Council (NSERC) of Canada (Grant \# RGPIN-2020-04585).

Institutional Review Board Statement: Not applicable.

Informed Consent Statement: Not applicable.

Data Availability Statement: Not applicable.

Acknowledgments: We acknowledge Alta Genetics Inc., Calgary, AB, Canada, for helpful discussions.

Conflicts of Interest: The authors have no conflict of interest. 


\section{References}

1. FAO. Transforming Food and Agriculture to Acheive the SDGs; FAO: Rome, Italy, 2018; p. 71. Available online: http://www.fao.org/ fao-stories/article/en/c/1184363/ (accessed on 1 September 2020).

2. Taylor, J.F.; Schnabel, R.D.; Sutovsky, P. Genomics of bull fertility. Animal 2018, 12, s172-s183. [CrossRef]

3. Gasparrini, B. In vitro embryo production in buffalo species: State of the art. Theriogenology 2002, 57, 237-256. [CrossRef]

4. Kumar, V. Genetic and breeding aspects of lactation. In Trends in Advance Veterinary Genetics, 1st ed.; Abubakar, M., Ed.; Intech Open: London, UK, 2017; p. 13.

5. Chesnais, J.P. How is the AI industry using genomic tools in practice? Interbull Bull. 2010, 41, $59-62$.

6. Kasinathan, P.; Wei, H.; Xiang, T.; Molina, J.A.; Metzger, J.; Broek, D.; Kasinathan, S.; Faber, D.C.; Allan, M.F. Acceleration of genetic gain in cattle by reduction of generation interval. Sci. Rep. 2015, 5, 8674. [CrossRef]

7. Vanraden, P.M. Selection on Net Merit to Improve Lifetime Profit. J. Dairy Sci. 2004, 87, 3125-3131. [CrossRef]

8. Aguilar, I.; Misztal, I.; Johnson, D.L.; Legarra, A.; Tsuruta, S.; Lawlor, T.J. Hot topic: A unified approach to utilize phenotypic, full pedigree, and genomic information for genetic evaluation of Holstein final score. J. Dairy Sci. 2010, 93, 743-752. [CrossRef] [PubMed]

9. Smith, M.F.; Geisert, R.D.; Parrish, J.J. Reproduction in domestic ruminants during the past 50 yr: Discovery to application. J. Anim. Sci. 2018, 96, 2952-2970. [CrossRef]

10. Rawlings, N.; Evans, A.C.O.; Chandolia, R.K.; Bagu, E.T. Sexual maturation in the bull. Reprod. Domest. Anim. 2008, 43, $295-301$. [CrossRef] [PubMed]

11. Goto, K.; Kinoshita, A.; Nakanishi, Y.; Ogawa, K. Blastocyst formation following intracytoplasmic injection of in-vitro derived spermatids into bovine oocytes. Hum. Reprod. 1996, 11, 824-829. [CrossRef] [PubMed]

12. Wang, B.; Baldassarre, H.; Pierson, J.; Cote, F.; Rao, K.M.; Karatzas, C.N. The in vitro and in vivo development of goat embryos produced by intracytoplasmic sperm injection using tail-cut spermatozoa. Zygote 2003, 11, 219-227. [CrossRef] [PubMed]

13. Stein, P.; Schultz, R.M. ICSI in the mouse. Method Enzymol. 2010, 476, 251-262.

14. Uehara, T.; Yanagimachi, R. Microsurgical injection of spermatozoa into hamster eggs with subsequent transformation of sperm nuclei into male pronuclei. Biol. Reprod. 1976, 15, 467-470. [CrossRef] [PubMed]

15. Lanzendorf, S.E.; Maloney, M.K.; Veeck, L.L.; Slusser, J.; Hodgen, G.D.; Rosenwaks, Z. A preclinical evaluation of pronuclear formation by microinjection of human spermatozoa into human oocytes. Fertil. Steril. 1988, 49, 835-842. [CrossRef]

16. De Abreu Santos, D.J.; Cole, J.B.; Liu, G.E.; VanRaden, P.M.; Ma, L. Gamevar.f90: A software package for calculating individual gametic diversity. BMC Bioinf. 2020, 21, 100. [CrossRef] [PubMed]

17. Lacham-kaplan, O.; Trounson, A. Intracytoplasmic sperm injection in mice: Increased fertilization and development to term after induction of the acrosome reaction. Hum. Reprod. 1995, 10, 2642-2649. [CrossRef]

18. Ahmadi, A.; Ng, S.C.; Liow, S.L.; Ali, J.; Bongso, A.; Ratnam, S.S. Intracytoplasmic sperm injection of mouse oocytes with 5 mM Ca 2+ at different intervals. Hum. Reprod. 1995, 10, 431-435. [CrossRef] [PubMed]

19. Palermo, G.; Joris, H.; Devroey, P.; Van Steirteghem, A.C. Pregnancies after intracytoplasmic injection of single spermatozoon. Lancet 1992, 340, 17-18. [CrossRef]

20. Colleoni, S.; Barbacini, S.; Necchi, D.; Ecar, D.; Duchi, R.; Lazzari, G. Application of ovum pick-up, intracytoplasmic sperm injection and embryo culture in equine practice. Reproduction 2007, 53, 554-559.

21. Kolbe, T.; Holtz, W. Birth of a piglet derived from an oocyte fertilized by intracytoplasmic sperm injection (ICSI). Anim. Reprod. Sci. 2000, 64, 97-101. [CrossRef]

22. Kurome, M.; Ueda, H.; Tomii, R.; Naruse, K.; Nagashima, H. Production of transgenic-clone pigs by the combination of ICSI-mediated gene transfer with somatic cell nuclear transfer. Transgen. Res. 2006, 15, 229-240. [CrossRef]

23. Graham, J.K.; Carnevale, E.M. Validation of a heterologous fertilization assay and comparison of fertilization rates of equine oocytes using in vitro fertilization, perivitelline, and intracytoplasmic sperm injections. Theriogenology 2014, 82, $274-282$.

24. Zhang, J.J.; Muzs, L.Z.; Boyle, M.S. In vitro fertilization of horse follicular oocytes matured in vitro. Mol. Reprod. Dev. 1990, 26, 361-365. [CrossRef] [PubMed]

25. Goto, K.; Kinoshita, A.; Takuma, Y.; Ogawa, K. Fertilisation of bovine oocytes by the injection of immobilised, killed spermatozoa. Vet. Rec. 1990, 127, 517-520. [PubMed]

26. Wei, H.; Fukui, Y. Births of calves derived from embryos produced by intracytoplasmic sperm injection without exogenous oocyte activation. Zygote 2002, 10, 149-153. [CrossRef] [PubMed]

27. Goto, K.; Yanagita, K. Normality of calves obtained by intracytoplasmic sperm injection. Hum. Reprod. 1995, 10, 1554-1556. [CrossRef] [PubMed]

28. Keskintepe, L.; Brackett, B.G. Cryopreservation of bovine blastocyst obtained by intracytoplasmic sperm injection. Theriogenology 2000, 53, 1041-1052. [PubMed]

29. Abdalla, H.; Shimoda, M.; Hara, H.; Morita, H.; Kuwayama, M. Vitrification of ICSI- and IVF-derived bovine blastocysts by minimum volume cooling procedure: Effect of developmental stage and age. Theriogenology 2010, 74, 1028-1035. [CrossRef]

30. Ock, S.; Kwack, D.; Lee, S.; Cho, S. In vitro development of bovine oocytes reconstructed with round spermatids. Theriogenology 2006, 65, 1242-1253. [CrossRef]

31. Lee, K.; Niwa, K. Fertilization and development in vitro of bovine oocytes following intracytoplasmic injection of heat-dried sperm heads. Biol. Reprod. 2006, 74, 146-152. [CrossRef] 
32. Keskintepe, L.; Pacholczyk, G.; Machnicka, A.; Norris, K.; Curuk, M.A.; Khan, I.; Brackett, B. Bovine blastocyst development from oocytes injected with freeze-dried spermatozoa. Biol. Reprod. 2002, 67, 409-415.

33. Rho, G.; Lee, S.; Kim, Y.; Yeo, H.; Ock, S.; Balasubramanian, S.; Choe, S.Y. Intracytoplasmic sperm injection of frozen-thawed bovine oocytes and subsequent embryo development. Mol. Reprod. Dev. 2004, 68, 449-455. [CrossRef] [PubMed]

34. Mavrides, A.; Morroll, D. Bypassing the effect of zona pellucida changes on embryo formation following cryopreservation of bovine oocytes. Eur. J. Obstet. Gynecol. Reprod. Biol. 2005, 118, 66-70. [CrossRef] [PubMed]

35. Ohlweiler, L.U.; Brum, D.S.; Leivas, F.G.; Moyses, A.B.; Ramos, R.S.; Klein, N.; Mezzalira, J.C.; Mezzalira, A. Intracytoplasmic sperm injection improves in vitro embryo production from poor quality bovine oocytes. Theriogenology 2013, 79, 778-783. [CrossRef]

36. Wilson, R.D.; Fricke, P.M.; Leibfried-rutledge, M.L. In vitro production of bovine embryos using sex-sorted sperm. Theriogenology 2006, 65, 1007-1015. [PubMed]

37. Wilson, R.D.; Weigel, K.A.; Fricke, P.M.; Rutledge, J.J.; Matthews, D.L.; Schutzkus, V.R. In vitro production of holstein embryos using sex-sorted sperm and oocytes from selected cull cows. J. Dairy Sci. 2005, 88, 776-782. [CrossRef]

38. Lu, K.H.; Cran, D.G.; Seidel, G.E. In vitro fertilization with flow-cytometrically-sorted bovine sperm. Theriogenology 1999, 52, 1393-1405. [CrossRef]

39. Jo, H.; Bang, J.; Kim, S.; Choi, B.; Jin, J.; Kim, H.; Jung, I.S.; Suh, T.K.; Ghanem, N.; Wang, Z.; et al. Production of female bovine embryos with sex-sorted sperm using intracytoplasmic sperm injection: Efficiency and in vitro developmental competence. Theriogenology 2014, 81, 675-682.e1.

40. Hamano, K.; Li, X.; Qian, X.; Funauchi, K.; Furudate, M.; Minato, Y. Gender preselection in cattle with intracytoplasmically injected, flow cytometrically sorted sperm heads. Biol. Reprod. 1999, 60, 1194-1197. [CrossRef]

41. Bevacqua, R.J.; Pereyra-Bonnet, F.; Fernandez-Martin, R.; Salamone, D.F. High rates of bovine blastocyst development after ICSI-mediated gene transfer assisted by chemical activation. Theriogenology 2010, 74, 922-931.

42. Sánchez-Villalba, E.; Elena, M.; Loren, P.; Fuentes, F.; Pereyra-Bonnet, F.; Salamone, D.; Felmer, R. Improved expression of green fluorescent protein in cattle embryos produced by ICSI-mediated gene transfer with spermatozoa treated with streptolysin-O. Anim. Reprod. Sci. 2018, 196, 130-137. [CrossRef]

43. Pereyra-Bonnet, F.; Fernandez-Martin, R.; Olivera, R.A.; Jarazo, J.A.; Vichera, G.A. A unique method to produce transgenic embryos in ovine, porcine, feline, bovine and equine species. Reprod. Fertil. Dev. 2008, 20, 741-749. [CrossRef] [PubMed]

44. Sekhavati, M.H.; Hosseini, S.M.; Tahmoorespur, M.; Ghaedi, K.; Jafarpour, F.; Hajian, M.; Dormiani, K.; Nasr-Esfahani, M.H. PhiC31-based site-specific transgenesis system for production of transgenic bovine embryos by somatic cell nuclear transfer and intracytoplasmic sperm injection. Cell J. 2018, 21, 98-107.

45. Terada, Y.; Hasegawa, H.; Takahashi, A.; Ugajin, T.; Yaegashi, N.; Okamura, K. Successful pregnancy after oocyte activation by a calcium ionophore for a patient with recurrent intracytoplasmic sperm injection failure, with an assessment of oocyte activation and sperm centrosomal function using bovine eggs. Fertil. Steril. 2009, 91, e11-e935. [CrossRef] [PubMed]

46. Yoshimoto-Kakoi, T.; Terada, Y.; Tachibana, M.; Murakami, T.; Yaegashi, N.; Okamura, K. Assessing centrosomal function of infertile males assessing centrosomal function of infertile males using heterologous ICSI. Syst. Biol. Reprod. Med. 2008, 54, 135-142. [CrossRef] [PubMed]

47. Nakamura, S.; Terada, Y.; Horiuchi, T.; Emuta, C.; Murakami, T.; Yaegashi, N.; Okamura, K. Human sperm aster formation and pronuclear decondensation in bovine eggs following intracytoplasmic sperm injection using a piezo-driven pipette: A novel assay for human sperm centrosomal function. Biol. Reprod. 2001, 65, 1359-1363. [CrossRef]

48. Nakamura, S.; Terada, Y.; Horiuchi, T.; Emuta, C.; Murakami, T.; Yaegashi, N.; Okamura, K. Analysis of the human sperm centrosomal function and the oocyte activation ability in a case of globozoospermia, by ICSI into bovine oocytes. Hum. Reprod. 2002, 17, 2930-2934. [PubMed]

49. Rawe, V.Y.; Terada, Y.; Nakamura, S.; Chillik, C.F.; Olmedo, S.B.; Chemes, H.E. A pathology of the sperm centriole responsible for defective sperm aster formation, syngamy and cleavage. Hum. Reprod. 2002, 17, 2344-2349. [CrossRef]

50. Wei, H.; Fukui, Y. Fertilisability of ovine, bovine or minke whale (Balaenoptera acutorostrata) spermatozoa intracytoplasmically injected into bovine oocytes. Zygote 2000, 8, 267-274. [CrossRef]

51. Kato, Y.; Nagao, Y. Changes in sperm motility and capacitation induce chromosomal aberration of the bovine embryo following intracytoplasmic sperm injection. PLoS ONE 2015, 10, e0129285. [CrossRef]

52. Terada, Y.; Nakamura, S.I.; Hewitson, L.; Simerly, C.; Horiuchi, T.; Murakami, T.; Okamura, K.; Schatten, G. Human sperm aster formation after intracytoplasmic sperm injection with rabbit and bovine eggs. Fertil. Steril. 2002, 77, 1283-1284. [CrossRef]

53. Salamone, D.F.; Canel, N.G.; Rodríguez, M.B. Intracytoplasmic sperm injection in domestic and wild mammals. Reproduction 2017, 154, 111-124. [CrossRef] [PubMed]

54. Águila, L.; Felmer, R.; Arias, M.E.; Navarrete, F.; Martin-Hidalgo, D.; Lee, H.C.; Visconti, P.; Fissore, R. Defective sperm head decondensation undermines the success of ICSI in the bovine. Reproduction 2017, 154, 307-318. [CrossRef] [PubMed]

55. Hara, H.; Abdalla, H.; Morita, H.; Kuwayama, M. Procedure for Bovine ICSI, not sperm freeze-drying, impairs the function of the microtubule-organizing center. J. Reprod. Dev. 2011, 57, 10-14. [CrossRef] [PubMed]

56. Malcuit, C.; Maserati, M.; Takahashi, Y.; Page, R.; Fissore, R.A. Intracytoplasmic sperm injection in the bovine induces abnormal [Ca 2+] i responses and oocyte activation. Reprod. Fertil. Dev. 2006, 18, 39-51. [CrossRef] [PubMed] 
57. Morozumi, K.; Yanagimachi, R. Incorporation of the acrosome into the oocyte during intracytoplasmic sperm injection could be potentially hazardous to embryo development. Proc. Natl. Acad. Sci. USA 2005, 102, 14209-14214. [CrossRef]

58. Garc1-Rosello, E.; Gracia-Mengual, E.; Coy, P.; Alfonso, J.; Silvestre, M.A. Intracytoplasmic sperm injection in livestock species: An update. Reprod. Domest. Anim. 2009, 44, 143-151. [CrossRef] [PubMed]

59. Nomikos, M. Novel signalling mechanism and clinical applications of sperm-specific PLC 乙. Biochem. Soc. Trans. 2015, 43, 371-376. [CrossRef]

60. Saunders, C.M.; Larman, M.G.; Parrington, J.; Cox, L.J.; Royse, J.; Blayney, L.M.; Blayney, L.M.; Swann, K.; Lai, F.A. PLC C: A sperm-specific trigger of Ca 2+ oscillations in eggs and embryo development. Development 2002, 129, 3533-3544.

61. Machaty, Z. Signal transduction in mammalian oocytes during fertilization. Cell Tissue Res. 2016, 363, 169-183.

62. Berridge, J.M.; Galione, A. Cytosolic calcium oscillators. FASEB J. 1988, 2, 3074-3082. [CrossRef]

63. Fujimoto, S.; Yoshida, N.; Fukui, T.; Amanai, M.; Isobe, T.; Itagaki, C.; Izumi, T.; Perry, A.C. Mammalian phospholipase Czeta induces oocyte activation from the sperm perinuclear matrix. Dev. Biol. 2004, 274, 370-383. [CrossRef] [PubMed]

64. Hewitson, L.; Dominko, T.; Takahashi, D.; Martinovich, C.; Ramalho-Santos, J.; Sutovsky, P.; Fanton, J.; Jacob, D.; Monteith, D.; Neuringer, M.; et al. Unique checkpoints during the first cell cycle of fertilization after intracytoplasmic sperm injection in rhesus monkeys. Nat. Med. 1999, 5, 431-433. [CrossRef] [PubMed]

65. Ramalho-Santos, J.; Sutovsky, P.; Simerly, C.; Oko, R.; Wessel, G.M.; Hewitson, L.; Schatten, G. ICSI choreography: Fate of sperm structures after monospermic rhesus ICSI and first cell cycle implications. Hum. Reprod. 2000, 15, 2610-2620. [CrossRef]

66. Sutovsky, P.; Manandhar, G.; Wu, A.; Oko, R. Interactions of sperm perinuclear theca with the oocyte: Implications for oocyte activation, anti-polyspermy defense, and assisted reproduction. Microsc. Res. Tech. 2003, 61, 362-378. [CrossRef] [PubMed]

67. Sutovsky, P.; Oko, R.; Hewitson, L.; Schatten, G. The removal of the sperm perinuclear theca and its association with the bovine oocyte surface during fertilization. Dev. Biol. 1997, 188, 75-84. [CrossRef]

68. Perreault, S.D.; Barbee, R.R.; Elstein, K.H.; Zucker, R.M.; Keefer, C.L. Interspecies differences in the stability of mammalian sperm nuclei assessed in vivo by sperm microinjection and in vitro by flow cytometry. Biol. Reprod. 1988, 39, 157-167. [CrossRef]

69. Yanagimachi, R. Mammalian Fertilisation. In The Physiology of Reproduction, 2nd ed.; Knobil, E., Neill, J., Eds.; Raven Press: New York, NY, USA, 1994; Volume 1, pp. 189-299.

70. Jager, S.; Wijchman, J.; Kremer, J. Studies on the decondensation of human, mouse, and bull sperm nuclei by heparin and other polyanions. J. Exp. Zool. 1990, 256, 315-322.

71. Maier, W.; Nussbaum, G.; Domenjoud, L.; Klemm, U.; Engel, W. The lack of protamine 2 (P2) in boar and bull spermatozoa is due to mutations within the P2 gene. Nucl. Acids Res. 1990, 18, 1249-1254. [CrossRef]

72. Brewer, L.; Corzett, M.; Lau, E.Y.; Balhorn, R. Dynamics of protamine 1 binding to single DNA molecules. J. Biol. Chem. 2003, 278, 42403-42408. [CrossRef]

73. Hutchison, J.M.; Rau, D.C.; Derouchey, J.E. Role of Disulfide Bonds on DNA Packaging Forces in Bull Sperm Chromatin. Biophys. J. 2017, 113, 1925-1933. [CrossRef]

74. Tayita, S.; Tamas, S.; Satoko, M.; Takashi, N.; Parnpai, R.; Geshi, M. Pretreatment of bovine sperm with dithiobutylamine (DTBA) significantly improves embryo development after ICSI. J. Reprod. Dev. 2016, 62, 577-585.

75. Sanchez, M.C.; Sedo, C.A.; Julianelli, V.L.; Romanato, M.; Calvo, L.; Calvo, J.C.; Fontana, V.A. Dermatan sulfate synergizes with heparin in murine sperm chromatin decondensation. Syst. Biol. Reprod. Med. 2013, 59, 82-90. [CrossRef] [PubMed]

76. Hochi, S. Microtubule assembly crucial to bovine embryonic development in assisted reproductive technologies. Anim. Sci. J. 2016, 87, 1076-1083. [PubMed]

77. Ushijima, H.; Nakane, T. Present status and prospects for bovine vitro-matured oocytes and frozen semen. J. Mamm. Ova Res. 2006, 23, 107-113. [CrossRef]

78. Hosseini, S.M.; Moulavi, F.; TanhaieVash, N.; Shams-Esfandabadi, N.; Nasr-Esfahani, M.H.; Shirazi, A. Evidence of oocyte polarity in bovine; implications for intracytoplasmic sperm injection and somatic cell nuclear transfer. Cell J. 2017, 19, 482-491.

79. Ashibe, S.; Miyamoto, R.; Kato, Y.; Nagao, Y. Detrimental effects of oxidative stress in bovine oocytes during intracytoplasmic sperm injection (ICSI). Theriogenology 2019, 133, 71-78. [CrossRef]

80. Wei, H.; Fukui, Y. Effects of bull, sperm type and sperm pretreatment on male pronuclear formation after intracytoplasmic sperm injaection in cattle. Reprod. Fertil. Dev. 1999, 11, 59-65. [CrossRef]

81. Katayose, H.; Yanagida, K.; Shinoki, T.; Kawahara, T.; Horiuchis, T.; Satol, A. Efficient injection of bull spermatozoa into oocytes using a piezo-driven pipette. Theriogenology 1999, 52, 1215-1224.

82. Yanagimachi, R. Intracytoplasmic sperm injection experiments using the mouse as a model. Hum. Reprod. 1998, 13, 87-98. [CrossRef]

83. Yanagimachi, R. Intracytoplasmic injection of spermatozoa and spermatogenic cells: Its biology and applications in humans and animals. Reprod. Biomed. Online 2005, 10, 247-288. [CrossRef]

84. Kasai, T.; Hoshi, K.; Yanagimachi, R. Effect of sperm immobilisation and demembranation on the oocyte. Zygote 1999, 7, 187-193. [CrossRef] [PubMed]

85. Suttner, R.; Zakhartchenko, V.; Stojkovic, P.; Muller, S.; Alberio, R.; Medjugorac, I.; Brem, G.; Wolf, E.; Stojkovic, M. Intracytoplasmic sperm injection in bovine: Effects of oocyte activation, sperm preteatment and injection technique. Theriogenology 2000, 54, 935-946. [CrossRef] 
86. Oikawa, T.; Itahashi, T.; Numabe, T. Improved embryo development in Japanese black cattle by in vitro fertilisation using ovum pick-up plus intracytoplasmic sperm injection with dithiothreitol. J. Reprod. Dev. 2016, 62, 11-16. [CrossRef] [PubMed]

87. Galli, C.; Vassiliev, I.; Lagutina, I.; Galli, A.; Lazzari, G. Bovine embryo development following ICSI: Effect of activation, sperm capacitation and pre-treatment with dithiothreitol. Theriogenology 2003, 60, 1467-1480. [CrossRef]

88. Rho, G.; Kawarsky, S.; Johnson, W.H.; Kochhar, K.; Betteridge, K.J. Sperm and oocyte treatments to improve the formation of male and female pronuclei and subsequent development following intracytoplasmic sperm injection into bovine oocytes. Biol. Reprod. 1998, 59, 918-924. [CrossRef] [PubMed]

89. Chung, J.; Keefer, C.; Downey, B. Activation of bovine oocytes following intracytoplasmic sperm injection. Theriogenology 1999, 53, 1273-1284.

90. Perreault, S.D.; Wolff, R.A.; Zirkin, B.R. The role of disulfide bond reduction during mammalian sperm nuclear decondensation in vivo. Dev. Biol. 1984, 101, 160-167. [CrossRef]

91. Oikawa, T.; Itahashi, T.; Yajima, R.; Numabe, T. Glutathione treatment of Japanese Black bull sperm prior to intracytoplasmic sperm injection promotes embryo development. J. Reprod. Dev. 2018, 64, 303-309. [CrossRef]

92. Lee, J.W.; Chang, H.C.; Wu, H.Y.; Liu, S.S.; Wang, C.H.; Chu, C.Y.; Shen, P.C. Effects of sperm pretreatment and embryo activation methods on the development of bovine embryos produced by intracytoplasmic sperm injection. Reprod. Biol. 2015, 15, 154-162. [CrossRef]

93. Águila, L.; Zambrano, F.; Arias, M.E.; Felmer, R. Sperm capacitation pretreatment positively impacts bovine intracytoplasmic sperm injection. Mol. Reprod. Dev. 2017, 84, 649-659.

94. Li, G.; Seidel, G.E.; Squires, E.L. Improved cleavage of bovine ICSI ova cultured in heparin-containing medium. Theriogenology 2004, 61, 1077-1084. [CrossRef] [PubMed]

95. Sekhavati, M.H.; Shadanloo, F.; Hosseini, M.S.; Tahmoorespur, M.; Nasiri, M.R.; Hajian, M.; Nasr-Esfahani, M.H. Improved bovine ICSI outcomes by sperm selected after combined heparin-glutathione treatment. Cell Reprogram. 2012, 14, 295-304. [CrossRef] [PubMed]

96. Canel, N.G.; Bevacqua, R.J.; Hiriart, M.I.; Rabelo, N.C.; de Almeida Camargo, L.S.; Romanato, M.; de Calvo, L.P.; Salamone, D.F. Sperm pretreatment with heparin and L-glutathione, sex-sorting, and double cryopreservation to improve intracytoplasmic sperm injection in bovine. Theriogenology 2017, 93, 62-70. [CrossRef] [PubMed]

97. Sánchez-Vázquez, M.L.; Flores-Alonso, J.C.; Merchant-Larios, H.; Reyes, R. Presence and release of bovine sperm histone H1 during chromatin decondensation by heparin-glutathione. Syst. Biol. Reprod. Med. 2008, 54, 221-230.

98. Lane, M.; Thérien, I.; Moreau, R.; Manjunath, P. Heparin and high-density lipoprotein mediate bovine sperm capacitation by different mechanisms. Biol. Reprod. 1999, 60, 169-175. [CrossRef] [PubMed]

99. Handrow, R.R.; Lenz, R.W. Structural comparison among glycosaminoglycans to promote an acrosome reaction in bovine spermatozoa. Biochem. Biophys. Res. Commun. 1982, 107, 1326-1332. [CrossRef]

100. Delgado, N.M.; Reyes, R.; Huacuja, L.; Merchant, H.; Rosado, A. Heparin binding sites in the human spermatozoa membrane Arch. Androl. 1982, 8, 87-95.

101. Romanato, M.; Cameo, M.S.; Bertolesi, G.; Baldini, C.; Calvo, J.C.; Calvo, L. Heparan sulphate: A putative decondensing agent for human spermatozoa in vivo. Hum. Reprod. 2003, 18, 1868-1873.

102. Romanato, M.; Regueira, E.; Cameo, M.S.; Baldini, C.; Calvo, L.; Calvo, J.C. Further evidence on the role of heparan sulfate as protamine acceptor during the decondensation of human spermatozoa. Hum. Reprod. 2005, 20, 2784-2789. [CrossRef]

103. Romanato, M.; Julianelli, V.; Zappi, M.; Calvo, L.; Calvo, J.C. The presence of heparan sulfate in the mammalian oocyte provides a clue to human sperm nuclear decondensation in vivo. Hum. Reprod. 2008, 23, 1145-1150. [CrossRef]

104. Zambrano, F.; Aguila, L.; Arias, M.E.; Sánchez, R.; Felmer, R. Improved preimplantation development of bovine ICSI embryos generated with spermatozoa pretreated with membrane-destabilizing agents lysolecithin and Triton X-100. Theriogenology 2016, 86, 489-497. [CrossRef] [PubMed]

105. Canel, N.G.; Suvá, M.; Bevacqua, R.J.; Arias, M.E.; Felmer, R.; Salamone, D.F. Improved embryo development using high cysteamine concentration during IVM and sperm co-culture with COCs previous to ICSI in bovine. Theriogenology 2018, 117, 26-33. [CrossRef] [PubMed]

106. Aris, M.E.; Sanchez, R.; Risopatron, J.; Perez, L.; Felmer, R. Effect of sperm pretreatment with sodium hydroxide and dithiothreitol on the efficiency of bovine intracytoplasmic sperm injection. Reprod. Fertil. Dev. 2014, 26, 847-854. [CrossRef]

107. Zambrano, F.; Aguila, L.; Arias, M.E.; Sanchez, R.; Felmer, R. Effect of sperm pretreatment with glutathione and membrane destabilizing agents lysolecithin and Triton X-100, on the efficiency of bovine intracytoplasmic sperm injection. Reprod. Domest. Anim. 2017, 52, 305-311. [CrossRef] [PubMed]

108. Tajik, P.; Niwa, K. Effects of caffine and/or heparin in a chemically defined medium with or without glucose on in vitro penetration of bovine oocytes and their subsequent development. Theriogenology 1998, 49, 771-777. [CrossRef]

109. Hwang, S.; Lee, E.; Yoon, J.; Yoon, B.K.; Lee, J.H.; Choi, D. Effects of electric stimulation on bovine oocyte activation and embryo development in intracytoplasmic sperm injection procedure. J. Assist. Reprod. Genet. 2000, 17, 310-314. [CrossRef]

110. Fujinami, N.; Hosoi, Y.; Kato, H.; Matsumoto, K.; Saeki, K.; Iritani, A. Activation with ethanol improves embryo development of ICSI-derived oocytes by regulation of kinetics of mpf activity. J. Reprod. Dev. 2004, 50, 171-178. [CrossRef] 
111. Vichera, G.; Alfonso, J.; Duque, C.C.; Silvestre, M.A.; Pereyra-Bonnet, F.; Fernández-Martín, R.; Salamone, D. Chemical activation with a combination of ionomycin and dehydroleucodine for production of parthenogenetic, ICSI and cloned bovine embryos. Reprod. Domest. Anim. 2010, 45, e306-e312. [CrossRef]

112. Ikumi, S.; Asada, M.; Sawai, K.; Fukui, Y. Effect of activation methods for bovine oocytes after intracytoplasmic injection. J. Reprod. Dev. 2003, 49, 37-43. [CrossRef]

113. Yang, X.; Presicce, G.A.; Moraghan, L.; Jiang, S.; Foote, R.H. Synergistic effect of ethanol and cyclohexidine on activation of freshly matured bovine oocytes. Theriogenology 1994, 41, 395-403. [CrossRef]

114. Abdalla, H.; Shimoda, M.; Hirabayashi, M.; Hochi, S. A combined treatment of ionomycin with ethanol improves blastocyst development of bovine oocytes harvested from stored ovaries and microinjected with spermatozoa. Theriogenology 2009, 72, 453-460. [CrossRef] [PubMed]

115. Horiuchi, T.; Emuta, C.; Yamauchi, Y.; Oikawa, T. Birth of normal calves after intracytoplasmic sperm injection of bovine oocytes: A methodological approach. Theriogenology 2002, 57, 1013-1024. [CrossRef]

116. Horiuchi, T. Application study of intracytoplasmic sperm injection for golden hamster and cattle production. J. Reprod. Dev. 2006, 52, 13-21. [CrossRef] [PubMed]

117. Oikawa, T.; Takada, N.; Kikuchi, T.; Numabe, T. Evaluation of activation treatments for blastocyst production and birth of viable calves following bovine intracytoplasmic sperm injection. Anim. Reprod. Sci. 2005, 86, 187-194. [CrossRef]

118. Cuthbertson, K.S.; Whittingham, D.G.; Cobbold, P.H. Free calcium increases in exponential phases during mouse oocyte activation Nature 1981, 294, 754-757. [CrossRef]

119. Masui, Y. From oocyte maturation to the in vitro cell cycle: The history of discoveries of maturation-promoting factor (MPF) and cytostatic factor (CSF). Differentiation 2001, 69, 1-17. [CrossRef]

120. Dunphy, W.G.; Brizuela, L.; Beach, D.; Newport, J. The xenopus cdc2 protein is a component of MPF, a cytoplasmic regulator of mitosis. Cell 1988, 54, 423-431. [CrossRef]

121. Labbe, J.C.; Picard, A.; Peaucellier, G. Purification of MPF from starfish: Identification as the H1 histone kinase p34 cdc2 and a possible mechanism for its periodic activation. Cell 1989, 57, 253-263. [CrossRef]

122. Clarke, P.R.; Karsenti, E. Regulation of p34 cdc2 protein kinase: New insights into protein phosphorylation and the cell cycle. J. Cell Sci. 1991, 100, 409-414.

123. Sagata, N.; Oskarsson, M.; Copeland, T.; Brumbaugh, J.; Vande Woude, G.F. Function of c-mos proto-oncogene product in meiotic maturation in Xenopus oocytes. Nature 1986, 335, 519-525. [CrossRef]

124. Watanabe, N.; Vande Woude, G.F.; Ikawa, Y.; Sagata, N. Specific proteolysis of the c-mos proto-oncogene product by calpain on fertilization of Xenopus eggs. Nature 1989, 342, 505-511. [CrossRef] [PubMed]

125. Ock, S.A.; Bhak, J.S.; Balasubramanian, S.; Lee, H.J.; Choe, S.Y.; Rho, G.J. Different activation treatments for successful development of bovine oocytes following intracytoplasmic sperm injection. Zygote 2003, 11, 69-76. [CrossRef] [PubMed]

126. Rho, G.J.; Wu, B.; Kawarsky, S.; Leibo, S.P.; Betteridge, K.J. Activation regimens to prepare bovine oocytes for intracytoplasmic sperm injection. Mol. Reprod. Dev. 1998, 50, 485-492. [CrossRef]

127. Devito, L.G.; Fernandes, C.B.; Blanco, I.D.; Tsuribe, P.M.; Landim-Alvarenga, F.C. Use of a piezo drill for intracytoplasmic sperm injection into cattle oocytes activated with ionomycin associated with roscovitine. Reprod. Domest. Anim. 2010, 45, 654-658. [CrossRef] [PubMed]

128. Fernandes, C.B.; Devito, L.G.; Martins, L.R.; Blanco, I.D.; de Lima Neto, J.F.; Tsuribe, P.M.; Gonçalves, C.G.; da Cruz Landim-Alvarenga, F. Artificial activation of bovine and equine oocytes with cycloheximide, roscovitine, strontium, or 6-dimethylaminopurine in low or high calcium concentrations. Zygote 2013, 22, 387-394. [CrossRef] [PubMed]

129. Szöllösi, M.S.; Kubiak, J.Z.; Debey, P.; de Pennart, H.; Szöllösi, D.; Maro, B. Inhibition of protein kinases by 6-dimethylaminopurine accelerates the transition to interphase in activated mouse oocytes. J. Cell Sci. 1993, 104, 861-872. [PubMed]

130. Coy, P.; Romar, R.; Payton, R.R.; McCann, L.; Saxton, A.M.; Edwards, J.L. Maintenance of meiotic arrest in bovine oocytes using the S-enantiomer of roscovitine: Effects on maturation, fertilization and subsequent embryo development in vitro. Reproduction 2005, 129, 19-26. [CrossRef]

131. Arias, M.E.; Sánchez, R.; Felmer, R. Effect of anisomycin, a protein synthesis inhibitor, on the in vitro developmental potential, ploidy and embryo quality of bovine ICSI embryos. Zygote 2016, 24, 724-732. [CrossRef]

132. Felmer, R.; Arias, M.E. Activation treatment of recipient oocytes affects the subsequent development and ploidy of bovine parthenogenetic and somatic cell nuclear transfer (SCNT) embryos. Mol. Reprod. Dev. 2015, 82, 441-449. [CrossRef]

133. Joiakim, A.; Mathieu, P.A.; Elliott, A.A.; Reiners, J.J., Jr. Superinduction of CYP1A1 in MCF10A cultures by cycloheximide, anisomycin, and puromycin: A process independent of effects on protein translation and unrelated to suppression of aryl hydrocarbon receptor proteolysis by the proteasome. Mol. Pharmacol. 2004, 66, 936-947. [CrossRef]

134. Ross, P.J.; Beyhan, Z.; Iager, A.E.; Yoon, S.Y.; Malcuit, C.; Schellander, K.; Fissore, R.A.; Cibelli, J.B. Parthenogenetic activation of bovine oocytes using bovine and murine phospholipase C zeta. BMC Dev. Biol. 2008, 8, 16. [CrossRef]

135. Okitsu, O.; Yamano, S.; Aono, T. Activation of bovine oocytes matured in vitro by injection of bovine and human spermatozoa or their cytosolic fractions. Zygote 2001, 9, 89-95. [CrossRef] [PubMed]

136. Parrington, J.; Swann, K.; Shevchenko, V.I.; Sesay, A.K.; Lai, F.A. Calcium oscillations in mammalian eggs triggered by a soluble sperm protein. Nature 1996, 379, 364-368. [CrossRef] [PubMed] 
137. Swann, K. A cytosolic sperm factor stimulates repetitive calcium increases and mimics fertilization in hamster eggs. Development 1990, 110, 1295-1302. [PubMed]

138. Swann, K.; Igusa, Y.; Miyazaki, S. Evidence for an inhibitory effect of protein kinase C on G-protein-mediated repetitive calcium transients in hamster eggs. EMBO J. 1989, 8, 3711-3718. [CrossRef] [PubMed]

139. Saunders, C.M.; Swann, K.; Lai, F.A. PLCzeta, a sperm-specific PLC and its potential role in fertilization. Biochem. Soc. Symp. 2007, 74, 23-36.

140. Swann, K.; Saunders, C.M.; Rogers, N.T.; Lai, F.A. PLC zeta: A sperm protein that triggers $\mathrm{Ca}^{2+}$ oscillations and egg activation in mammals. Semin. Cell Dev. Biol. 2006, 17, 264-273. [CrossRef]

141. Parrington, J.; Lai, F.A.; Swann, K. A novel protein for $\mathrm{Ca}^{2+}$ signaling at fertilization. Curr. Top. Dev. Biol. 1998, 39, $215-243$.

142. Amdani, S.N.; Yeste, M.; Jones, C.; Coward, K. Sperm factors and oocyte activation: Current controversies and considerations. Biol. Reprod. 2015, 93, 50. [CrossRef]

143. Miyazaki, S.; Shirakawa, H.; Nakada, K.; Honda, Y. Essential role of the inositol 1,4,5-trisphosphate receptor/Ca ${ }^{2+}$ release channel in $\mathrm{Ca}^{2+}$ waves and $\mathrm{Ca}^{2+}$ oscillations at fertilization of mammalian eggs. Dev. Biol. 1993, 158, 62-78. [CrossRef]

144. Swann, K.; Yu, Y. The dynamics of calcium oscillations that activate mammalian eggs. Int. J. Dev. Biol. 2008, 52, 585-594. [CrossRef] [PubMed]

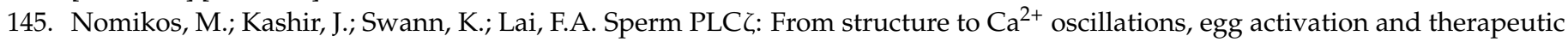
potential. FEBS Lett. 2013, 587, 3609-3616. [CrossRef] [PubMed]

146. Wu, A.T.; Sutovsky, P.; Manandhar, G.; Xu, W.; Katayama, M.; Day, B.N.; Park, K.W.; Yi, Y.J.; Xi, Y.W.; Prather, R.S.; et al. PAWP, a sperm-specific WW domain-binding protein, promotes meiotic resumption and pronuclear development. J. Biol. Chem. 2007, 282, 12164-12175. [CrossRef]

147. Aarabi, M.; Balakier, H.; Bashar, S.; Moskovtsev, S.I.; Sutovsky, P.; Librach, C.L.; Oko, R. Sperm-derived WW domain-binding protein, PAWP, elicits calcium oscillations and oocyte activation in humans and mice. FASEB J. 2014, 28, 4434-4440. [CrossRef] [PubMed]

148. Aarabi, M.; Qin, Z.; Xu, W.; Mewburn, J.; Oko, R. Sperm-borne protein, PAWP, initiates zygotic development in Xenopus laevis by eliciting intracellular calcium release. Mol. Reprod. Dev. 2010, 77, 249-256. [CrossRef]

149. Nomikos, M.; Sanders, J.R.; Theodoridou, M.; Kashir, J.; Matthews, E.; Nounesis, G.; Lai, F.A.; Swann, K. Sperm-specific post-acrosomal WW-domain binding protein (PAWP) does not cause Ca2+ release in mouse oocytes. Mol. Hum. Reprod. 2014, 20, 938-947. [CrossRef]

150. Heytens, E.; Parrington, J.; Coward, K.; Young, C.; Lambrecht, S.; Yoon, S.Y.; Fissore, R.A.; Hamer, R.; Deane, C.M.; Ruas, M.; et al. Reduced amounts and abnormal forms of phospholipase C zeta (PLC z) in spermatozoa from infertile men. Hum. Reprod. 2009, 24, 2417-2428. [CrossRef]

151. Kashir, J.; Konstantinidis, M.; Jones, C.; Lemmon, B.; Lee, H.C.; Hamer, R.; Heindryckx, B.; Deane, C.M.; De Sutter, P.; Fissore, R.A.; et al. A maternally inherited autosomal point mutation in human phospholipase C zeta (PLC z) leads to male infertility. Hum. Reprod. 2012, 27, 222-231. [CrossRef]

152. Knott, J.G.; Kurokawa, M.; Fissore, R.A.; Schultz, R.M.; Williams, C.J. Transgenic RNA interference reveals role for mouse sperm phospholipase Czeta in triggering Ca2+ oscillations during fertilization. Biol. Reprod. 2005, 72, 992-996. [CrossRef]

153. Yoon, S.Y.; Jellerette, T.; Salicioni, A.M.; Lee, H.C.; Yoo, M.S.; Coward, K.; Parrington, J.; Grow, D.; Cibelli, J.B.; Visconti, P.E.; et al. Human sperm devoid of PLC, zeta 1 fail to induce Ca 2+ release and are unable to initiate the first step of embryo development. J. Clin. Investig. 2008, 118, 3671-3681. [CrossRef]

154. Wassarman, P.M.; Albertini, D.F. The Mammalian Ovum. In The Physiology of Reproduction, 2nd ed.; Knobil, E., Neill, J., Eds.; Raven Press: New York, NY, USA, 1988; Volume 1, pp. 79-122.

155. Anifandis, G.; Messini, C.I.; Dafopoulos, K.; Daponte, A.; Messinis, I.E. Sperm contributions to oocyte activation: More that meets the eye. J. Assist. Reprod. Genet. 2016, 33, 313-316. [CrossRef] [PubMed]

156. Nomikos, M.; Swann, K.; Lai, F. Starting a new life: Sperm PLC zeta mobilizes the calcium signal that induces egg activation and embryo development: An essential phospholipase C with implication for male infertility. Bioessays 2011, 34, 126-134. [CrossRef] [PubMed]

157. Ito, M.; Shikano, T.; Oda, S.; Horiguchi, T.; Tanimoto, S.; Awaji, T.; Mitani, H.; Miyazaki, S. Difference in Ca ${ }^{2+}$ oscillation-inducing activity and nuclear translocation ability of PLCZ1, an egg-activating sperm factor candidate, between mouse, rat, human, and medaka fish. Biol. Reprod. 2008, 78, 1081-1090. [CrossRef] [PubMed]

158. Yoneda, A.; Kashima, M.; Yoshida, S.; Terada, K.; Nakagawa, S.; Sakamoto, A.; Hayakawa, K.; Suzuki, K.; Ueda, J.; Watanabe, T. Molecular cloning, testicular postnatal expression, and oocyte-activating potential of porcine phospholipase Czeta. Reproduction 2006, 132, 393-401. [CrossRef]

159. Cox, L.J.; Larman, M.G.; Saunders, C.M.; Hashimoto, K.; Swann, K.; Lai, F.A. Sperm phospholipase Czeta from humans and cynomolgus monkeys triggers $\mathrm{Ca}^{2+}$ oscillations, activation and development of mouse oocytes. Reproduction 2002, 124, 611-623. [CrossRef]

160. Tomes, C.N. Activation of mouse sperm phosphatidylinositol-4,5 bisphosphate-phospholipase C by zona pellucida is modulated by tyrosine phosphorylation. Mol. Reprod. Dev. 1996, 43, 196-204. [CrossRef]

161. Rajamanickam, G.D.; Kastelic, J.P.; Thundathil, J.C. Content of testis-specific isoform of Na/K-ATPase (ATP1A4) is increased during bovine sperm capacitation through translation in mitochondrial ribosomes. Cell Tissue Res. 2017, 368, 187-200. [CrossRef] 
162. Rajamanickam, G.D.; Kastelic, J.P.; Thundathil, J.C. Testis-specific isoform of Na/K-ATPase (ATP1A4) interactome in raft and non-raft membrane fractions from capacitated bovine sperm. Int. J. Mol. Sci. 2019, 20, 3159.

163. Thundathil, J.C.; Rajamanickam, G.D.; Kastelic, J.P. Na/K-ATPase and regulation of sperm function. Anim. Reprod. 2018, 15, 711-720. [CrossRef]

164. Flesch, F.M.; Colenbrander, B.; van Golde, L.M.; Gadella, B.M. Capacitation induces tyrosine phosphorylation of proteins in the boar sperm plasma membrane. Biochem. Biophys. Res. Commun. 1999, 262, 787-792. [CrossRef]

165. Brener, E.; Rubinstein, S.; Cohen, G.; Shternall, K.; Rivlin, J.; Breitbart, H. Remodeling of the actin cytoskeleton during mammalian sperm capacitation and acrosome reaction. Biol. Reprod. 2003, 68, 837-845. [CrossRef]

166. Salicioni, A.M.; Platt, M.D.; Wertheimer, E.V.; Arcelay, E.; Allaire, A.; Sosnik, J.; Visconti, P.E. Signalling pathways involved in sperm capacitation. Soc. Reprod. Fertil. Suppl. 2007, 65, 245-259.

167. Thundathil, J.C.; Anzar, M.; Buhr, M.M. Na/K-ATPase as a signaling molecule during bovine sperm capacitation. Biol. Reprod. 2006, 75, 308-317. [CrossRef]

168. Newton, L.D.; Krishnakumar, S.; Menon, A.G.; Kastelic, J.P.; van der Hoorn, F.A.; Thundathil, J.C. Na/K-ATPase regulates sperm capacitation through a mechanism involving kinases and redistribution of its testis-specific isoform. Mol. Reprod. Dev. 2010, 77, 136-148. [PubMed]

169. Anapalakan, A. Sodium-Potassium-ATPase Signalling Mechanism Inducing Capacitation in Bull Sperm. Ph.D. Thesis, University of Guelph, Guelph, ON, Canada, 2010.

170. Yuan, Z.; Cai, T.; Tian, J.; Ivanov, A.V.; Giovannucci, D.R.; Xie, Z.Y. Na/K-ATPase tethers phospholipase C and IP3 receptor into a calcium-regulatory complex. Mol. Biol. Cell 2005, 16, 4034-4045. [CrossRef] [PubMed]

171. Thundathil, J.C.; Rajamanickam, G.D.; Kastelic, J.P.; Newton, L.D. The effects of increased testicular temperature on testis-specific isoform of $\mathrm{Na} / \mathrm{K}$-ATPase in sperm and its role in spermatogenesis and sperm function. Reprod. Domest. Anim. 2012, 47, 170-177. [CrossRef] [PubMed]

172. Rajamanickam, G.D.; Kastelic, J.P.; Thundathil, J.C. Na/K-ATPase regulates bovine sperm capacitation through raft- and non-raft-mediated signaling mechanisms. Mol. Reprod. Dev. 2017, 84, 1168-1182. [CrossRef] 